\title{
2. Rosneft: lord of the rigs ${ }^{1}$
}

Rosneft is Russia's national oil company. Its evolution mirrors that of the relationship between the state and oil corporations in post-Soviet Russia. Rosneft was born from the ashes of the Soviet state structures in the early 1990s but went into a seemingly terminal decline as the feisty oligarchs hacked away at its assets during this chaotic decade. However, the rise of Vladimir Putin and his entourage gave Rosneft a new lease of life, and in the 2000s, it came to be the Tyrannosaurus rex of the Russian petroleum sector. It grew mainly through acquisitions, beginning with Yuganskneftegaz and YUKOS in 2004 and 2007, respectively. With Igor Sechin as chairman of its board from 2004 and then President from 2012, the company bought three of Russia's other major oil and gas companies - TNK-BP, Itera and Bashneft - becoming the world's largest publicly traded oil company by hydrocarbon reserves and production. This history of rise and fall and rise again contrasts with that of Russia's other major state company, Gazprom. Gazprom's position as the blue whale of the Russian gas sector during this period was far more consistent and stable.

In 2018, Rosneft produced 230 million tonnes of oil and condensate, up $2.1 \%$ from 2017 . That year, its gas production amounted to 67 billion cubic metres. Its proved reserves of hydrocarbons grew by $4 \%$ to 41 billion barrels of oil equivalent. Rosneft is also the largest Russian refiner, handling 103 million tonnes of oil in 2018 (Rosneft 2019b). It controls 13 major refineries, three petrochemical companies and four gas-processing plants. It also owns shares in three German refineries and a stake in the Mozyr refinery in Belarus. Its petroleum product distributors operate in 66 regions of Russia and other post-Soviet states. As of December 2016, the company had a network of 2962 gas stations.

Rosneft contributed to transforming Russian foreign energy policy by turning to Chinese and Indian partners, driven by both commercial motives and political necessity. Rosneft actively established strategic partnerships with international oil companies both in Russia and abroad. Before the imposition of the Western sanctions in connection with the conflict in Ukraine, Rosneft was engaged in developing shale oil, Arctic offshore fields and other parts of Russia's continental shelf.

Rosneft invests significant effort in monitoring and forecasting oil prices and macroeconomic trends. However, given its strong political ties, it is also well aware that the state will pitch in to help it cope with unforeseen developments. 
As of April 2018, Rosneft's main shareholder was the state-owned vehicle Rosneftegaz, which held $50.00000001 \%$ of the company's stock (Table 2.1). In November 2019, the company's market capitalization was USD 74 billion, less than those of Chevron, Equinor or ExxonMobil but greater than ENI, Gazprom or LUKOIL (Bloomberg 2019).

\section{Table 2.1 Rosneft's shareholders}

\begin{tabular}{ll}
\hline Shareholder & \% of stock \\
\hline Rosneftegaz & 50.00000001 \\
BP & 19.75 \\
QHG Oil Ventures & 19.50 \\
National Settlement Depository & 10.38 \\
Federal State Property Agency & One share \\
\hline
\end{tabular}

Source: Rosneft website.

\section{CORPORATE HISTORY: EVOLVING ROSNEFT IN AN EVOLVING RUSSIA}

\section{The 1990s: The Birth and Near-Death Experience of Rosneft}

Rosneft originated in the state corporation Rosneftegaz, which was established in October 1991 on the basis of the dismantled USSR Ministry for the Oil Industry. Presidential Decree 1403 of 17 November $1992^{2}$ created vertically integrated oil companies LUKOIL, YUKOS and Surgutneftegas, the state enterprise Rosneft, as well as the Transneft and Transnefteproduct transportation companies. Rosneft was expected to manage government stakes in 259 (out of 301) oil industry enterprises and perform additional non-commercial functions. These included supporting the restructuring of the joint stock companies (JSCs), ensuring deliveries of fuel to cover state needs, coordinating government investments in the sector and organizing the manufacture of oilfield equipment (Hudson and Poussenkova 1996). At the time, Rosneft was headed by Alexander Putilov, the former General Director of Uraineftegaz now a LUKOIL subsidiary.

In 1993, Rosneft accounted for more than $60 \%$ of Russian oil production. Given all the other problems of the transition period, the Russian state struggled to manage this giant conglomerate. The company's complicated organizational structure, including 26 oil-producing associations, 23 refineries, several gas-processing plants and several petroleum product suppliers and research institutes, hardly facilitated the management of the company.

Between 1993 and 1995, several new vertically integrated oil companies were carved out of the assets controlled by Rosneft: Slavneft, SIDANCO, Sibneft, 
TNK, Eastern Oil Company, ONACO and KomiTEK. As a result, Rosneft kept shrinking. The creation of Sibneft, which included Noyabrskneftegaz (a 22-million-tonne-per-annum oil producer) and Omsknefteorgsyntez (the most advanced refinery in Russia), hit Rosneft particularly hard.

Presidential Decree 327 of 1995 transformed the state enterprise Rosneft into an open joint stock company (OJSC). ${ }^{3}$ However, the losses continued: Rosneft was deprived of a stake in the Moscow refinery and Mosnefteprodukt, which it had held in trust management (Neft i kapital 2004a, p. 14). In 1997, the government decided to sell Krasnodarnefteorgsyntez because of tax debts of USD 32 million, and it was eventually auctioned off in 2000 (NGFR 2008).

Rosneft also nearly lost Purneftegaz - its key oil-producing subsidiary based in Yamal-Nenets Autonomous District (YNAO). When SIDANCO was established in May 1994, Purneftegaz was transferred to it. In early 1995, the leadership of Purneftegaz asked the government to return it to Rosneft, and it was handed back, but SIDANCO initiated a lawsuit to challenge the decision (Latyshova 1995, pp. 46-51). This tug of war continued for two years, but when the courts eventually recognized SIDANCO's claims, Vladimir Potanin, the owner of SIDANCO, unexpectedly returned it to Rosneft (Neft i kapital 2004b, p. 60).

Having lost valuable assets throughout the 1990s, Rosneft ended up as a minor player, accounting for only $7 \%$ of Russia's crude output and reserves. However, it managed to remain a tempting target for the oligarchs. Several attempts were made to privatize Rosneft during the 1990s, but the company remained under state patronage. In April 1997, Alexander Putilov was dismissed as Rosneft's President because he resisted the State Property Committee's plans to privatize the company (NGFR 2008). Since he still had influential friends, he was made the chairman of the board of directors, whereas Yuri Bespalov, representing Boris Berezovskiy - the most powerful oligarch of the 1990s - became President. Bespalov started preparing the company to be bought by Sibneft.

Attempts to privatize Rosneft in 1997 failed because influential players had an interest in delaying the process. The most controversial attempt was made in 1998. Just before his resignation, Prime Minister Victor Chernomyrdin approved a plan to sell $75 \%+1$ share of Rosneft for USD 2.1 billion plus USD 400 million to be invested in future projects to be implemented by the new owner of Rosneft. The auction was scheduled for 29 May 1998, and a fierce battle was expected between the competing alliances of SIDANCO-BP, Gazprom-Shell-LUKOIL and Yuksi (YUKOS-Sibneft) (Samoilova 1998). However, the May auction was a fiasco since the foreign investors stayed away, and the sale was postponed until 30 October. The sale price was reduced to USD 1.6 billion and the investment conditions to USD 65 million (Poluektov 1998). The government fired both Putilov and Bespalov and hired 
the Alliance Group led by Ziya Bazhayev, the former President of SIDANCO, to prepare Rosneft for the auction. By this time, Rosneft was in a desperate situation with large debts, unmanageable subsidiaries and 40 enterprises whose assets had been seized. Yet in just two weeks, Bazhayev and his team significantly enhanced Rosneft's investment appeal through restructuring. However, on 17 August 1998, the worst financial crisis in Russian history erupted, and the auction was postponed indefinitely.

In October 1998, Sergei Bogdanchikov, the former Head of Sakhalinmorneftegaz, was appointed President of Rosneft. He faced a mission impossible: to restore a company that had almost entirely disintegrated. Bogdanchikov immediately started setting his house in order. He appointed loyal people to run Rosneft's key production units Purneftegaz and Sakhalinmorneftegaz and made it mandatory for the managers of subsidiaries to obtain his personal approval of any hiring and firing, business plans and loans and government relations. He also forced them to channel all oil exports through the Rosneft holding (Neft i kapital 2004c, p. 161).

\section{The 2000s: The Rebirth of Rosneft}

When Sergei Bogdanchikov became the President of Rosneft, nobody expected that he would hold on to this position for long, as he was neither a political heavyweight nor a protégée of the oligarchs. However, he soon found a powerful sponsor at the very top - President Vladimir Putin - who needed a mighty state oil company to counterbalance the voracious private corporations. Thus, the year 2000 marked the start of a new chapter in Rosneft's life.

Sergei Bogdanchikov started by consolidating Rosneft's control over its subsidiaries. In 2000, the government allowed Rosneft to increase its stake in its subsidiaries to $75 \%$, and it began to buy their shares on the secondary market. The renaissance of Rosneft was primarily accomplished through aggressive acquisitions, beginning in 2003 with Severnaya Neft with 17 oilfields in the Timan-Pechora province (Derbilova and Tutushkin 2004).

The rising status of Rosneft was confirmed in July 2004 when Igor Sechin, Deputy Head of the Presidential Administration and one of the most influential people in Russia, was made the chairman of Rosneft's board of directors, ensuring strong political patronage for the company. Rosneft became a national champion: owing to its large hydrocarbon reserves and political connections, it was expected to compete against the global majors, protect the national petroleum wealth and implement the government's energy policy.

Rosneft joined the big league in 2004 when it acquired Yuganskneftegaz - the key producing subsidiary of YUKOS - after Gazprom failed to secure this prize asset. In the early 2000s, before it was acquired by Rosneft, Yuganskneftegaz demonstrated double-digit crude output growth, mainly 
owing to the intensification of oil production practised by YUKOS and the commissioning of the Priobskoye field. When the government began the crackdown on YUKOS in the autumn of 2003, YUKOS was hit with a tax bill of USD 28 billion for the period 1999-2003 and Yuganskneftegaz was subsequently put up for sale (Poussenkova and Overland 2018).

It was widely expected that Gazprom would snap up Yuganskneftegaz. However, YUKOS sought court protection in Houston under Chapter 11 of the US law on bankruptcy. The court vetoed the Yuganskneftegaz auction and forbade Gazprom and six international banks from participating in the auction. The bankers obeyed, and Gazprom lost the chance of raising the foreign loans it needed to carry out the transaction. Despite this decision, the auction took place on 19 December 2004: the unknown company Baikal Finance Group, registered on the eve of the auction in the provincial town of Tver, bought Yuganskneftegaz for USD 9.35 billion (Mescherin 2005, p. 5). Three days later, Rosneft purchased Baikal Finance Group for a trifling RUB 10000.

Having bought Yuganskneftegaz, Rosneft was transformed from a second-tier player with 21 million tonnes of oil production per annum into a 75-million-tonne-per-annum giant. At the same time, Rosneft became Russia's second-largest borrower after Gazprom. In early 2005, its debt amounted to USD 22.5 billion, and the rating agency Standard and Poor's (S\&P) downgraded its credit rating from B to B- (Vinogradova 2005, p. 29).

It is worth noting that at the same time, in 2004, Rosneft was once again in danger of losing its independence. In September 2004, President Putin had approved a government proposal to incorporate Rosneft into the structure of Gazprom in exchange for $10.74 \%$ of its shares that were held by its subsidiaries. This would have permitted the state to increase its stake in Gazprom and to liberalize the trade in its shares. However, Gazprom realized that the reputational risks were too high. Moreover, Rosneft's value drastically increased after the purchase of Yuganskneftegaz, placing it beyond Gazprom's reach. Instead, Gazprom bought $72.6 \%$ of Sibneft's shares for USD 13 billion in September 2005 (see the chapter on Gazprom Neft in this book).

Ultimately, the government changed its plans diametrically. It transferred $100 \%$ of Rosneft's shares - then valued at USD 26 billion - to the ownership vehicle Rosneftegaz, which subsequently raised the necessary debt to purchase $10.74 \%$ of Gazprom's shares. After that, Rosneftegaz organized an initial public offering of Rosneft shares to repay the debt.

To raise money for the purchase of Yuganskneftegaz, Rosneft generated USD 6.1 billion by selling short-term bonds, and received another USD 1.8 billion of credit from Sberbank (Derbilova and Kudinov 2005). Vnesheconombank bought short-term bonds worth USD 5.3 billion from Rosneft using funds from the Ministry of Finance, which had been intended to repay Russia's external debt. In early 2005, Vnesheconombank raised USD 
6 billion for Rosneft from Chinese banks. In exchange, Rosneft pledged to deliver 48 million tonnes of oil to CNPC up to 2010 (Derbilova 2006). With support from the Head of State and a powerful political figure on its board of directors, Rosneft had access to ministerial finances and carried out energy diplomacy on behalf of the Russian state.

It is paradoxical that during the 1990s, when broad privatization was ongoing in Russia, Rosneft remained under the wing of the state, but in the 2000 s, when the étatization of the oil sector began, the company was partially privatized. Its initial public offering (IPO) took place in 2006: $14.8 \%$ of the shares were sold for USD 10.4 billion. The share price was USD 7.55, corresponding to a capitalization of USD 79.8 billion. Rosneft's IPO was the largest ever in Russia and the fifth largest in world history. Russian oligarchs Roman Abramovich, Oleg Deripaska and Vladimir Lisin paid USD 1 billion for stakes in Rosneft, thus making important political investments. BP, CNPC (China) and Petronas (Malaysia) bought shares worth USD 1 billion, USD 1.1 billion and USD 500 million, respectively. In addition, a people's IPO was organized for the citizens of Russia. As a result, 115000 Russians became shareholders of Rosneft, spending USD 750000 in total (Derbilova and Surzhenko 2006).

The bankruptcy of YUKOS in 2007 was another important milestone in Rosneft's evolution. Rosneft competed with Gazprom for the remaining assets of YUKOS, and the two state companies managed to obtain what they wanted: mainly oil assets in the case of Rosneft and gas assets in the case of Gazprom.

A scandal erupted during the sale of the YUKOS oil assets. In May 2007, the most expensive lot was sold, consisting of the eastern assets of YUKOS: Tomskneft, Vostsibneftegaz, the Angarsk Petrochemical Company and the Achinsk refinery. A Rosneft subsidiary, Neft-Aktiv, bought the lot at a price just above the starting price of USD 6.8 billion (Surzhenko and Mazneva 2007). However, soon Rosneft announced that it would sell a $50 \%$ stake in Tomskneft to Vnesheconombank for USD 3.4 billion. Analysts believed that Vnesheconombank planned to purchase this stake for Gazprom Neft. In the summer of 2007, Rosneft announced that the deal was closed, but Vladimir Dmitriev, Head of Vnesheconombank, denied that such a deal had taken place, while the bank's supervisory board stated that it had not reviewed the transaction (Petrachkova and Derbilova 2007). The scandal was hushed up, and in December 2007 Gazprom Neft acquired half of Tomskneft directly for USD 3.6 billion (Petrachkova and Derbilova 2007).

Rosneft won five out of 12 YUKOS bankruptcy auctions. Through these acquisitions, it improved its production/refining ratio and became the number one player in eastern Russia. It also became the world's largest public oil company by liquid hydrocarbon reserves (Surzhenko and Mazneva 2007). However, its debt rose to USD 36 billion, and, as a precautionary measure, in 2007, the government added Rosneft to its list of strategic enterprises that 
could be bankrupted only under a special procedure (Mazneva and Derbilova 2007).

Rosneft further strengthened its position in 2008 when Igor Sechin, the chairman of its board of directors, became Deputy Prime Minister with special responsibility for the fuel and energy sector. In May 2008, S\&P upgraded its long-term credit rating from $\mathrm{BB}+$ to $\mathrm{BBB}$ - (stable forecast), reflecting the benefits of Sechin's new position for Rosneft.

Combined with the financial crisis of 2008, the debts that Rosneft had incurred due to the acquisition of YUKOS forced it to seek out Chinese capital again. In February 2009, after hard bargaining with the Chinese and Igor Sechin personally leading the negotiations, Rosneft received a loan worth USD 15 billion from China. At the same time, the Chinese banks granted USD 10 billion to Transneft, mainly for the construction of the ESPO pipeline, including a spur to China. In return, the two state companies pledged to deliver 15 million tonnes per annum to China for 20 years (see also the section on internationalization below), with Vankor field playing a key role in these supplies.

The commissioning of the Vankor oil, gas and condensate field in 2009 is one of Rosneft's greatest triumphs. Located in Krasnoyarsk Krai, Vankor is the largest field discovered and launched in Russia in a quarter of a century. Vankor is actually a cluster of fields, with proved oil reserves exceeding 500 million tonnes and gas reserves of 182 billion cubic metres. Rosneft acquired Vankorneft in 2004, wresting it from YUKOS and Total.

Vankor was expected to reach a production of 25 million tonnes per annum at peak. However, the field peaked at 22 million tonnes per annum in 2014, staying at this level for three years and accounting for $11-12 \%$ of Rosneft's output. Production then began to fall, and there were fears that this trend might accelerate and reduce the output to 13 million tonnes by 2020 (Fadeeva 2016d). Rosneft anticipated that between 2016 and 2020, the development of the Suzunskoye, Tagulskoye and Lodochnoye fields of the Vankor cluster would offset the decline.

\section{Post-2010: Further Expansion}

In June 2010, Sergei Bogdanchikov's directorship expired, and there was another change of guard at Rosneft. Rumours had long been circulating about Bogdanchikov's possible dismissal mainly because of his troubled relationship with Sechin (Derbilova and Reznik 2010). In September 2010, President Dmitriy Medvedev, who had long been connected with Rosneft's rival Gazprom, appointed Eduard Khudainatov, Head of Gazprom subsidiary Severneftegazprom, to the presidency of Rosneft. Rosneft's acquisition spree continued under Khudainatov; it bought Taas-Yuryakh Neftegazodobycha, for 
example, and established strategic alliances with foreign majors - both trends likely masterminded by Igor Sechin.

In May 2012, just after the re-election of Putin as Russian President, the next phase of Rosneft's development was launched: the 'Rosneftization' of the Russian oil sector. Igor Sechin became the company's CEO and embarked on a new wave of major acquisitions.

In March 2013, Rosneft acquired TNK-BP. It bought BP's 50\% stake in the company for USD 16.65 billion and $12.84 \%$ of Rosneft's shares, while BP purchased $5.66 \%$ of Rosneft's shares from Rosneftegaz, becoming the second-largest shareholder of Rosneft after the state with 19.75\% (it had bought $1.25 \%$ during Rosneft's IPO). Rosneft also bought a stake of the Alfa-Access-Renova (AAR) consortium in TNK-BP for USD 27.73 billion. Rosneft raised USD 51 billion for the purchase, including USD 31 billion of credits from foreign banks (Solodovnikova 2013). As a result of the acquisition, Rosneft was transformed into the world's largest public oil company in terms of both hydrocarbons production and reserves (Rosneft 2013a). Rosneft benefited by obtaining several of TNK-BP's international projects and attractive gas assets as well as prolific reserves in Western Siberia (such as the legendary Samotlor field ${ }^{4}$ ) and Eastern Siberia.

Rosneft's acquisition of TNK-BP inspired a new round of China-Russia oil cooperation in 2013. Two major oil export contracts were signed in 2013. The first contract was between Rosneft and CNPC for the delivery of 360 million tonnes of crude over 25 years and was worth USD 270 billion with a stipulated advance payment of USD 65 billion. The second contract was with Sinopec and worth USD 85 billion for 100 million tonnes of crude over ten years. This enabled the acquisitions spree to continue with the purchase of the independent gas producer Itera, oil assets of ALROSA and Sibneftegaz (Rosneft 2013b, 2013c; Stulov 2016a).

In October 2016, the federal government found that it urgently needed money for the state budget and wanted to raise it through the privatization of several companies. Initially, there were plans to hold a public auction for Bashneft - a company formerly owned by the regional government of Bashkortostan - which had been privatized in 2002-03 but then seized by the Russian government in 2014. LUKOIL, NNK (Nezavisimaya Neftegazovaya Kompaniya of Eduard Khudainatov) and other players were interested in Bashneft's assets. Some government officials who were against Rosneft's participation in this auction argued that it would not add money to the state coffers if one state company bought another (Fadeeva et al. 2016a). But Igor Sechin actively lobbied for Rosneft's interests, and ultimately it turned out to be the only contender for the stake. Through this acquisition, Rosneft's production of liquids grew by $10 \%$ and oil refining by $20 \%$. Sechin argued that the acquisition of Bashneft would raise the capitalization of Rosneft, making 
it possible to subsequently privatize $19.5 \%$ of Rosneft for over USD 11 billion (Stulov 2016b).

While Rosneft's close ties to the Kremlin often helped it achieve its objectives, in some cases they proved detrimental to the company. In the summer of 2014, following the conflict in Ukraine, the United States imposed personal sanctions against Igor Sechin and financial sanctions against Rosneft; Canada and the European Union (EU) also introduced sanctions against Rosneft (Fjaertoft and Overland 2015; Politinformatsia 2015). In addition, Rosneft was affected by the sectoral sanctions specifically targeting the Arctic, deep-water and shale projects. Moreover, in 2015, Rosneft's subsidiaries were also added to the US sanctions list (Usov et al. 2015). Igor Sechin complained that the inclusion of Rosneft on the sanctions list was 'unsubstantiated, subjective and illegal because the company played no role in the Ukrainian crisis' (Newsru. com 2014).

The next phase of Rosneft's privatization took place in 2016. When the government drew up plans to continue the privatization of the company to replenish the state coffers in the mid-2010s, Igor Sechin was against the idea. He argued that it would be more efficient to sell $19.5 \%$ of Rosneft when oil prices rebounded to the level of USD 100 per barrel (Fadeeva 2016a). However, other government officials insisted on the further partial privatization of Rosneft, overcoming his objections. Experts predicted that either CNPC would buy a $19.5 \%$ stake in Rosneft or Rosneft would find a way to buy itself (Barsukov et al. 2016). In autumn 2016, Igor Sechin held negotiations with some 30 potential investors. Finally, to everyone's surprise, a 50:50 consortium between Glencore and the Qatar Investment Authority purchased the stake for EUR 10.2 billion (less than the government had expected) (Fadeeva et al. 2016b). Rosneftegaz covered the difference by issuing additional dividends of RUB 18 billion. The consortium financed the deal from its own funds (EUR 2.8 billion) and bank funds (EUR 7.4 billion), mainly from Intesa Sanpaolo. Later, information leaked out that Gazprombank and VBRR (All-Russian Bank for Regional Development) had also helped the consortium to raise money (Stulov 2016c).

In 2017, Igor Sechin suddenly found another potential investor for Rosneft, the largely unknown Chinese company CEFC, which was expected to buy the lion's share of the stake held by the consortium. However, these plans did not materialize after CEFC's Head was detained in China on suspicion of economic crimes in early 2018 (Petleva 2018).

Due to its wide range of privatization schemes and acquisitions, Rosneft has a highly internationalized board of directors. From September 2017 onwards, seven out of 11 directors were foreigners; the chairman was also a foreigner - the former German Chancellor Gerhard Schroeder. There were also three foreigners on the 11-member board. 


\section{COMPANY PROFILE}

As a result of its many acquisitions, Rosneft has a highly diverse portfolio of oil and gas assets, consisting of very mature oilfields in the centre of the European part of Russia, mature fields in Western Siberia, relatively young fields in Western Siberia and Timan-Pechora, young fields in Eastern Siberia, offshore producing fields in the Sakhalin-1 project and untapped reserves in the Arctic seas.

\section{Offshore}

Rosneft has always made an effort to develop its offshore operations. However, the results have been mixed, mainly because of geological issues and domestic and international economics and politics. Rosneft started to expand its Arctic offshore operations in the early 2000s. In 2001, Gazprom and Rosneft established the joint venture Sevmorneftegaz to develop several northern fields, including Kharampurskoye, Prirazlomnoye and Shtokmanovskoye. By 2002, Rosneft had gained de facto control over the projects of Sevmorneftegaz, and it was thought that its central role in the development of the Prirazlomnoye field could enable the company to take on a leading role on the Russian Arctic continental shelf (Neft i kapital 2003, p. 24). However, in 2005, Rosneft had to sell its stake in the joint venture to Gazprom to pay for the acquisition of YUKOS's former crown jewel - Yuganskneftegaz.

In the early 2000s, Rosneft also consolidated its position on Sakhalin by launching other offshore projects in addition to Sakhalin-1, in which it had been involved since 1996, when the relevant production-sharing agreement (PSA) was signed. In 2002, together with BP, it received the geological licences for Sakhalin-4 and Sakhalin-5. BP was to finance the exploration. However, both projects failed: the first two wells drilled on the Zapadno-Schmidtovskiy block were dry, and in 2009, the partners gave up Sakhalin-4. In 2007, they discovered a field within Kaigansko-Vasyukanskiy block, but BP considered it commercially unattractive and withdrew from Sakhalin-5 in 2011 (Gavshina 2011).

In August 2003, Rosneft won a five-year exploration licence for the Western Kamchatka continental shelf and signed a memorandum of understanding with the Korean National Oil Corporation (KNOC) in September 2004. Again, the foreigners were to cover the exploration expenses. However, in August 2008, Rosnedra (Federal Agency for Subsoil Use) refused to extend the exploration licence because of non-fulfilment of the drilling plan by Rosneft, and this asset was transferred to Gazprom as the company responsible for the gasification of Kamchatka. 
Rosneft has also been active in the Sea of Azov and the Black Sea since 2002. Together with LUKOIL and the Administration of Krasnodar Krai, Rosneft established Priazovneft to assess and develop the reserves of the Sea of Azov. In spring 2003, Rosneft and Total signed an agreement on the joint exploration of the Black Sea, including the Tuapse Trough. However, their partnership did not last, mainly because of the controversies surrounding Vankor.

Under an important piece of legislation passed in 2008, only Gazprom and Rosneft were eligible to work on Russia's continental shelf, most of which is located in the Arctic. However, a lack of funds, technology, know-how and skills for the Arctic offshore operations forced Rosneft to sign strategic partnership agreements with foreign companies. By aggressively purchasing offshore licences, Rosneft managed to become the most significant player in the Russian offshore oil and gas sector. As of January 2017, it has held 56 licences for plots in the Arctic and in Russia's easternmost and southernmost seas (Table 2.2).

\section{Table 2.2 Rosneft's offshore projects}

\begin{tabular}{lll}
\hline Area & Sea & Projects \\
\hline Western Arctic & Barents, Pechora and Kara Seas & 19 \\
Eastern Arctic & Laptev, East Siberian and Chukchi Seas & 9 \\
Far East & Okhotsk and Japanese Seas & 20 \\
Southern seas & Black, Azov and Caspian Seas & 8 \\
\hline
\end{tabular}

Source: Rosneft (2018a).

Having become the world's largest public oil company in terms of liquids production, Rosneft began to make a bet on new offshore projects with international partners (Table 2.3). In June 2010, Rosneft invited Chevron to participate in its Black Sea ventures: Val Shatskogo and the adjacent Tuapse Trough. Again, foreigners were required to finance the exploration phase (Mazneva and Novy 2010). However, in spring 2011, dissatisfied with the results of seismic exploration and unhappy with Rosneft's certain terms of cooperation, Chevron withdrew from the project (Melnikov 2011a).

Almost at the same time, on 27 January 2011, Rosneft and ExxonMobil reached an agreement on the joint development of hydrocarbon resources of the Black Sea - primarily the Tuapse Trough. Rosneft also decided to expand its offshore cooperation with BP. On 14 January 2011, the companies signed an agreement to develop the Arctic jointly and swap shares. However, despite the blessing of the then Prime Minister Vladimir Putin, the Russian oligarch shareholders of TNK-BP, known as the AAR consortium, torpedoed the 
BP-Rosneft partnership (Poussenkova 2012). After the collapse of the deal with BP, Rosneft did not hesitate to find another partner. In summer 2011, Rosneft and ExxonMobil signed a strategic cooperation agreement.

In April 2012, following Gazprom's and Rosneft's strong lobbying, the government issued an ordinance aimed at providing fiscal and tariff incentives for the development of the Russian continental shelf (Rosneft 2012a). For example, offshore projects were given exemption from export duty as well as a lower rate of mineral production tax $(5-15 \%$ depending on the complexity of the project); moreover, stability assurances of these terms were allowed for 15 years. Invited by Rosneft (and encouraged by the new fiscal benefits), other foreign companies - for example, ENI in April 2012 and Statoil (now Equinor) in May 2012 - gained a foothold in the Russian offshore sector. The terms for ENI, ExxonMobil and Equinor were almost identical: they were to bear the burden of the expenses at the exploration phase, and joint ventures were required to be established with Rosneft, which held $66.7 \%$ while the foreign company held 33.3\% (Overland et al. 2013).

Table 2.3 Rosneft's strategic partnerships

\begin{tabular}{|c|c|c|c|}
\hline $\begin{array}{l}\text { Foreign } \\
\text { companies }\end{array}$ & Main assets & $\begin{array}{l}\text { Other partnership elements in } \\
\text { Russia }\end{array}$ & $\begin{array}{l}\text { International projects } \\
\text { offered to Rosneft }\end{array}$ \\
\hline ExxonMobil & $\begin{array}{l}\text { Kara Sea (Vostochno- } \\
\text { Prinovozemelskiye 1-3), } \\
\text { Black Sea (Tuapse Trough) }\end{array}$ & $\begin{array}{l}\text { ExxonMobil to assist Rosneft } \\
\text { in developing hard-to-recover } \\
\text { reserves in Western Siberia }\end{array}$ & $\begin{array}{l}\text { Exploration projects } \\
\text { in the Gulf of Mexico, } \\
\text { the United States and } \\
\text { Canada }\end{array}$ \\
\hline ENI & $\begin{array}{l}\text { Black Sea (Val Shatskogo), } \\
\text { Barents Sea (Fedynsk and } \\
\text { Tsentralno-Barentsevsk) }\end{array}$ & - & $\begin{array}{l}\text { International projects } \\
\text { primarily in North } \\
\text { Africa }\end{array}$ \\
\hline Equinor & $\begin{array}{l}\text { Barents Sea (Perseevskiy), } \\
\text { Okhotsk Sea (Magadan-1, } \\
\text { Lisyanskiy, Kashevarovskiy) }\end{array}$ & $\begin{array}{l}\text { Equinor to assist in the } \\
\text { development of shale oil in } \\
\text { the Samara region and the } \\
\text { highly viscous oil of the } \\
\text { Severo-Komsomolsk field in } \\
\text { Yamal-Nenets Autonomous } \\
\text { District }\end{array}$ & $\begin{array}{l}\text { Norwegian offshore } \\
\text { and international } \\
\text { projects of Equinor }\end{array}$ \\
\hline
\end{tabular}

Source: Rosneft (2019a).

Rosneft also invited companies from other countries, such as PetroVietnam and Japanese INPEX, to cooperate on offshore developments, but these partnerships did not move beyond expressing good intentions. Because of issues related to both geology and international politics, cooperation with ENI, Equinor and ExxonMobil had limited success. In September 2016, Rosneft and Equinor drilled two exploration wells in the Okhotsk Sea at a depth of less 
than 150 metres, meaning that the Western sanctions would not apply. Yet both wells yielded only water (Fadeeva 2016b). In August 2014, Rosneft and ExxonMobil began drilling the northernmost well in Russia in the Kara Sea, the USD 600-million Universitetskaya-1. A month and a half later, partners discovered a new field; oil was found at the Vostochno-Prinovozemelskiy-1 block. However, due to the US sanctions, ExxonMobil had to halt its offshore operations in the Russian Arctic, which meant that Rosneft would not be able to proceed without its partner.

In April 2017, Rosneft began drilling the Central Olginskaya-1 well in the Laptev Sea, the first ever well in this sea. The Laptev Sea might contain 9.5 billion tonnes of oil equivalent; however, there are no ports in the vicinity of the well, and the navigation period is only two months per year. Drilling was being conducted by RN-Bureniye, the service division of Rosneft (Rosneft 2017b). This endeavour was Rosneft's acid test of whether it could conduct an Arctic offshore operation alone. In June 2017, Rosneft announced the discovery of a new field in this area (Markova 2017). However, it is still unclear whether the company will be able to develop this field on its own.

As the development of the Arctic is the key focus of Rosneft's offshore portfolio, the company has sought to build its capacities to manufacture offshore equipment and vessels capable of operating in the Arctic. Its main effort has been aimed at creating the Zvezda shipbuilding complex in the Russian Far East as part of a consortium involving Rosneftegaz and Gazprombank and creating partnerships with the leading international manufacturers of offshore equipment (Table 2.4). The several agreements that were signed after 2014 attest that sanctions did not entirely succeed in restricting Rosneft's access to international technology.

Table 2.4 Rosneft's main offshore technology partnerships

\begin{tabular}{|c|c|c|c|}
\hline Foreign partner & Country & Year & (Possible) areas of cooperation \\
\hline Siemens & Germany & 2014 & $\begin{array}{l}\text { Shipbuilding, 'digital wharf', subsea systems, floating } \\
\text { production storage and offloading (FPSO) units }\end{array}$ \\
\hline General Electric & $\begin{array}{l}\text { United } \\
\text { States }\end{array}$ & 2016 & $\begin{array}{l}\text { Manufacture of steering wheels for vessels, electronic } \\
\text { naval equipment and dynamic positioning for ice-class } \\
\text { vessels }\end{array}$ \\
\hline Keppel/MH Wirth & Singapore & 2016 & Shipbuilding design and engineering \\
\hline $\begin{array}{l}\text { Hyundai Heavy } \\
\text { Industries }\end{array}$ & Korea & 2016 & Aframax tankers \\
\hline $\begin{array}{l}\text { Samsung Heavy } \\
\text { Industries }\end{array}$ & Korea & 2018 & Arctic shuttle tankers \\
\hline $\begin{array}{l}\text { Gaztransport \& } \\
\text { Technigaz }\end{array}$ & France & 2017 & LNG vessels \\
\hline
\end{tabular}




\section{Shale Reserves}

Rosneft is keen to develop unconventional reserves, but this also requires international partners. Hard-to-recover projects became commercially more attractive for foreign companies after amendments to the tax legislation introduced in September 2013. Under these amendments, the Abalac, Bazhenov, Domanic and Khadum formations were exempted from the mineral production tax for 15 years (Rosneft 2013d). Rosneft entered into partnerships to develop unconventional reserves with ExxonMobil, BP and Equinor (Rosneft 2013e, 2014).

However, Western sanctions created serious obstacles for these partnerships. For instance, the establishment of a joint venture between BP and Rosneft was frozen. The sanctions notwithstanding, the partners sometimes managed to bypass the restrictions: despite the EU sanctions, in early 2017, a joint venture between Rosneft and Equinor began drilling on the Domanic formations in the Samara region. Equinor seemingly managed to prove that these formations were limestone rather than shale and, therefore, not subject to the sanctions (Kozlov et al. 2017).

\section{CSR}

Rosneft publishes an annual sustainability report, covering issues related to labour protection, health, safety and environment (HSE) and the contributions of the company and its subsidiaries to the socio-economic development of the regions where they operate. The reports are produced in accordance with the requirements of the Global Reporting Initiative (GRI), the United Nations (UN) Global Compact and other nationally and internationally recognized sustainability reporting guidelines (see Rosneft 2017a, pp. 10-11 and Annex 2).

Gerhard Schroeder's opening message of the 2017 Sustainability Report as chairman of the board hardly makes a reference to the environment, climate, society or sustainable development. Instead, it focuses on the sustained growth of the business. However, CEO Igor Sechin's message outlines Rosneft's strategic goals in this area, starting with HSE:

Building a business that meets the highest HSE standards is an essential element of Rosneft's strategy. We are determined to make it to the upper quartile of global oil and gas companies in terms of HSE performance by 2022. (Rosneft 2017a, p. 5)

Sechin particularly emphasizes that Rosneft's membership of the UN Global Compact (since 2010) is a vehicle for promoting sustainability, 'focusing closely on innovations and initiatives to tackle climate change' (see section on climate change below). Sechin adds that 'innovation growth, biodiversity 
conservation and the sustainable use of water are also high on the priority list' (Rosneft 2017a, p. 5). In terms of social support, Sechin states thus:

Rosneft is Russia's largest taxpayer and undertakes major social projects, many of which have completely changed the social landscape in both large cities and smaller communities by facilitating public access to modern medical, educational, recreational, sport and utility services. (Rosneft 2017a, p. 5)

In 2018, Gerhard Schroeder spoke about Rosneft and sustainable development and climate change:

Rosneft is fully aware of the role it plays in advancing the sustainability agenda and is involved in efforts to address global issues. In a public statement released last year regarding its contribution to the 17 UN Sustainable Development Goals, the Company highlighted five priority goals on its agenda: Good Health and Well-Being, Affordable and Clean Energy, Decent Work and Economic Growth, Climate Action, and Partnerships for the Goals. (Rosneft 2018b, p. 3)

Sechin's opening message in the 2018 Sustainability Report mentions HSE and the company's commitment to the UN Sustainable Development Goals:

In the next four years, the company plans to join the first quartile of world oil and gas companies in terms of HSE. To strengthen the Company's position in the areas of environmental and social responsibility, Rosneft's ... commitment to the $17 \mathrm{UN}$ Sustainable Development Goals was approved in 2018. (Rosneft 2018b, p. 5)

Rosneft has released joint declarations on environmentally sustainable Arctic offshore developments with its business partners ExxonMobil and Statoil (in 2012, now Equinor) and ENI (in 2013). In these agreements, the partners reaffirm their commitment to the sustainable development of the Arctic, including minimizing their impact on indigenous people and climate change (Rosneft 2012b). In 2014, Rosneft launched a marine conservation programme for the Arctic which included support for environmental protection, research and monitoring (Rosneft 2017a, p. 76). Rosneft's regional subsidiaries also fund scientific research programmes, such as Evenki reindeer protection in Krasnoyarsk region and taimen trout protection on Sakhalin Island.

In 2017, Rosneft updated its Sustainable Development Policy, with new sections on energy efficiency and conservation as well as emergency preparedness and response. This document also includes a human rights element, along with HSE and stakeholder engagement. It is publicly available online (Rosneft 2017c). Rosneft also has a Code of Business Ethics covering stakeholder and business relations and issues such as fraud, corruption and conflicts of interest. A growing area of interest and concern for Rosneft is cyber-security and the need to adapt effectively to the digital era. 
Rosneft was ranked seventh in the 2018 World Wildlife Fund (WWF)/ Creon rating of the environmental performance of Russian oil and gas companies, which is a significant rise of ten places compared to 2017 (Shvarts et al. 2018). It achieved this through substantial improvements in its information disclosure, despite having dropped ten places in the ranking for its environmental impact.

In its sustainability report, Rosneft reports on its stakeholder engagement, noting that the most important types of engagement are public consultations on potential environmental impacts and regular roundtable meetings, which Rosneft has been holding since 2007 in host regions to share views and maintain partnership relations with local authorities and other stakeholders. In 2017, the company reported a total of 127 public awareness efforts of various types in different regions, including over 50 public consultations (for example, public hearings and surveys) to discuss offshore exploration activities and 15 roundtable meetings in various host regions (Rosneft 2017a, pp. 48-9).

In 2018, the company reported over 220 public awareness measures of various types in its regions of operation, including 16 public consultations and 16 roundtable meetings (Rosneft 2018b, p. 29).

Rosneft also has a strong focus on research and development (R\&D), providing support to a range of specialized institutes and plans to establish a Technology Council to drive innovation throughout the company; it also has a programme for import substitution and localization (Rosneft 2017a).

In addition to its sponsorship of targeted R\&D for its core business, Rosneft also supports the state education policy. Its representatives participate in the boards of trustees and the supervisory boards of nine higher education institutions. Rosneft helped establish a grammar school under the auspices of Moscow State University; it also finances the development of research and education infrastructure of naval higher education institutions, such as the Saint Petersburg State Naval Technical University and the Makarov State University of the Sea and River Fleet to train engineers for the shipbuilding industry. The company funds 17 chairs in the country's leading higher education institutions and provides some grants and scholarships to students.

Like other Russian oil companies, Rosneft signs agreements with the local authorities in the regions where it operates and funds individual charitable projects (in education and science, healthcare, sport, culture, 'revival of spiritual heritage' and environmental protection). For example, in September 2017, Rosneft and the Republic of Sakha-Yakutiya signed an agreement to finance social projects in the republic: Rosneft pledged to provide financial support for the construction of an education and laboratory building for the Yakutsk Academy of Sciences and a national research and education centre for 150 pupils specializing in physics, mathematics, sciences, information technology (IT) and engineering near Yakutsk (Rosneft 2017d). 
As the national oil company (NOC) of Russia, Rosneft is tasked by the state with additional non-commercial functions, which transcend corporate social responsibility (CSR) in the way it is practised by international oil companies and, in return, receives additional benefits from the state. When Rosneft was weak, it welcomed the non-commercial functions, probably wishing to demonstrate its usefulness to its owner. However, as Rosneft grew stronger, its mindset changed and it began to present itself as a global energy company rather than a domestically oriented NOC; it also began to consider its social obligations as a burden that might prevent it from fulfilling its duty to its shareholders. Nonetheless, it believed that the additional benefits that accompanied the company for being an NOC belonged to it by right.

In the early 2000s, Rosneft was ordered to resuscitate Chechnya's oil sector, which had been devastated by war. This task combined CSR elements and support for Russian federalism and territorial integrity. In 2000, Rosneft established a subsidiary, Grozneftegaz (51\% Rosneft; 49\% government of Chechnya). Rosneft rebuilt 256 destroyed facilities and increased oil production in Chechnya from 0.7 million tonnes in 2001 to 2 million tonnes in 2004 (Neft i kapital 2004d, p. 37). However, this growth was not sustainable; by 2011, production had fallen back to 803000 tonnes of oil and 0.3 billion cubic metres of gas, declining to 300000 tonnes of oil in 2018. In 2010, Rosneft's board of directors voted to build a refinery in Grozny (capacity: 1 million tonnes per annum by 2013); however, the project stalled. Some progress was made in 2013 when Vladimir Putin ordered an evaluation of the possibility of building a refinery in Chechnya, and Rosneft was officially charged with the project. However, in 2016, it was postponed to a future unspecified date. The construction of a small refinery in Chechnya appeared unprofitable to Rosneft in the then macroeconomic environment, so it decided to forgo its non-commercial obligation in favour of its duty to its shareholders.

\section{COPING WITH CHANGE}

\section{Predicting Oil Prices}

Rosneft is fully aware of the importance of oil prices for its business. Thus, it highlighted in its 2016 Annual Report that for its operational results the following main macroeconomic factors were of paramount importance: growth rate of the world economy and the Russian economy, the level of inflation in Russia and the rouble/dollar exchange rate and global oil and gas prices. Rosneft monitors the development of global oil prices continuously. The company's CEO is famous for his predictions (sometimes wrong, sometimes right) of the oil price. For example, in September 2014, when the oil prices had just begun falling, Igor Sechin said in an interview with TASS that 'The oil price 
will not drop below USD 90 per barrel. It is connected with several factors. But USD 90 is also a good price. It permits working. Rosneft's budget would not suffer. It is based on a price that does not exceed this level' (Igor Sechin, cited in Gordeyev 2017).

Sechin is particularly famous for his regular oil price predictions at the Saint Petersburg International Economic Forum, and the energy session where he usually delivers a presentation is one of the forum's most popular events. It is interesting to compare and verify the accuracy of his 2015, 2016 and 2017 predictions in Saint Petersburg.

In 2015, Sechin predicted that the oil price would grow to USD 170 by 2035. He also stated that the current oil price was characterized by 'elements of dumping' and the desire to redistribute the market; however, he believed that such phenomena could not be sustainable in the longer term. He stated that if the oil price did not correspond to objective requirements, both consumers and producers would suffer in the future (Igor Sechin, cited in Kalyukov 2015). Sechin argued that only minimal costs were factored into the current oil prices, which did not take into account the so-called full-cycle costs, in particular, the cost of decommissioning of depleted wells: 'The investments of transnational companies in major projects are already drastically decreasing. As a result, within 2-3 years, production might be significantly reduced' (Igor Sechin, cited in Kalyukov 2015). Igor Sechin also noted that many OPEC countries faced a severe budget deficit and tried to increase their revenues by exceeding the established production quotas: 'The policy of the USD 50-60 per barrel range has natural limitations in terms of time frame' (Igor Sechin, cited in Kalyukov 2015). He believed that the drastic drop of oil prices aggravated the fight for market shares, and, as a result, in May 2015, the imbalance between supply and demand in the oil market achieved a record high level of 3 million barrels per day: 'Some players make a bet on dumping, while others on fundamental, longer-term factors. Life will show who has been more successful and farsighted' (Igor Sechin, cited in Kalyukov 2015).

In 2016 at the Saint Petersburg Forum, Sechin noted the unpredictability of the main actors of the global oil market (Razumovskiy 2016). He warned that the balance which the market was just beginning to achieve could be disturbed at any moment and argued that Russia was one of the most reliable market actors: 'the market mechanisms of the functioning of the oil sector have been deformed' (Igor Sechin, cited in Razumovskiy 2016). He noted that there were many reasons for this situation: a focus on short-term financial instruments and the manipulation of market institutions to the detriment of the producer-consumer relations. While the market was moving towards a mid-term balance at the time, it might be disturbed at any moment because of the unpredictable behaviour of the producers who played the role of regulators in the global market (Razumovskiy 2016). 
At the 2017 Saint Petersburg Forum, Igor Sechin said that low oil prices were here to stay. Although the OPEC+ agreement in late 2016 gave the market some breathing space, he believed its long-term effect would be limited. He reminded his audience that several major producers who did not join the agreement actively used the market situation to strengthen their own market positions, thus laying the ground for a new wave of instability. Shale oil producers in the United States were becoming major exporters, and production in Nigeria and Libya was growing. Investments in new projects began to decline and would affect the oil sector in the near future. Soon, the balance of the market at the level of USD 40 per barrel would cause about half of the world's producers to make a loss. He believed that Brazilian deep-water projects, Canadian oil sands and many US shale producers (except the most efficient sections of the Permian Basin) would suffer, while Russia, Saudi Arabia, Iran and several successful projects in the United States would remain competitive. He also stated that market uncertainty resulted in a growing fight over consumers and that all market participants were getting ready to raise their output (Newsru.com 2017).

In 2017, Igor Sechin made a prediction about the oil price in 2018 . He believed that it would be in the range of USD 40-43 per barrel; in other words, it would return to the level of early 2016, mainly due to the growing production of shale oil (Gazeta.ru 2017). He was overly pessimistic - or perhaps he was just being a cautious, responsible manager - but he was right that shale oil would hold back the oil price. In 2018, Sechin predicted that the oil price in 2019 would be USD 53-60 per barrel, largely due to a rise in the interest rate in the United States (RBC.ru 2018).

\section{Handling Oil Price Fluctuations and Sanctions}

At the start of the 2008 financial crisis, Rosneft was the only company among the top five Russian oil companies that did not plan to cut back investments in 2009; instead, it decided to save on electricity and fuel and 'optimize' its staffing. It developed its 2009 budget realistically proceeding from the oil price of USD 50 per barrel (-26.5\% compared to the 2008 level) (Malkova and Derbilova 2008).

In response to the 2008 crisis, Rosneft stopped recruiting new workers and sacked 9000 people, equivalent to some 5\% of its staff. These cuts mainly affected temporary employees and workers close to the retirement age (Malkova 2009). During the first half of 2009, the company's operating expenses (including salaries) fell by $12.3 \%$ to USD 1.8 billion, while administrative and general economic expenses (including salaries of personnel at headquarters and management of subsidiaries) fell by $14.3 \%$ to USD 676 
million. On the other hand, it paid outsize bonuses in 2008 to personnel at headquarters where 1537 people worked.

In the years after 2008, Rosneft continued to compensate for falling oil prices by raising efficiency and exercising strict cost control. Some analysts believed that it was the most efficient company in the Russian petroleum sector in that period (Malkova 2010).

Another measure that aimed at cushioning the impact of low oil prices involved lobbying for tax benefits for Vankor, which yielded successful results. Tax breaks included reducing the export duty to some $30 \%$ of the standard rate. This helped the company save up to USD 3 billion in 2010 (Mazneva et al. 2010) - a privilege that would be revoked in 2011. However, Rosneft requested the government to prolong the partial tax holiday for Vankor until 2014 when the field was expected to reach its peak production of 25 million tonnes per annum. In return, the company guaranteed the Ministry of Finance a fixed amount of fiscal revenues (Gavshina 2011).

Rosneft had to respond to the 2014 oil price collapse, the economic crisis in Russia and Western sanctions concurrently. Since these developments, alongside the colossal debts incurred in connection with numerous acquisitions from 2004 onwards, seriously strained the company's financial position, it used its considerable lobbying clout to obtain financial benefits from the government and more loans from China.

Due to the sanctions, Rosneft lost about USD 20 billion in capitalization by mid-2015. The losses were genuine because credits and equipment became more expensive, and many opportunities were missed because the Arctic offshore projects were halted. In early 2014, before the events in Ukraine, Rosneft's value on the London Stock Exchange (LSE) was some USD 80 billion; by mid-2015, it was about USD 40 billion, although this decline also partly resulted from low oil prices.

Continuing this trend, Rosneft lobbied for unprecedented tax benefits for the Samotlor field in October 2017. The mineral production tax was reduced by RUB 35 billion for ten years (although, initially, Rosneft had sought a reduction of RUB 70 billion); in return, Rosneft promised to increase investments in the field and raise production (Kozlov and Barsukov 2017). In 2016, investments in Samotlor grew by $38 \%$, although production declined moderately.

In 2014, as an anti-crisis measure, Rosneft attempted to obtain money from the National Wealth Fund for its projects. The National Wealth Fund is Russia's stabilization fund and, according to the Ministry of Finance, is intended to help ensure the long-term stability of Russian pensions. In 2014, Rosneft applied to the National Wealth Fund for RUB 2.4 trillion to aid the development of East Siberian gas fields and the construction of the Eastern Petrochemical Company (Papchenkova and Tretyakov 2014). In January 2015, Rosneft increased the number of projects in the application for financing from the National Wealth 
Fund from 12 to 28 (Papchenkova et al. 2015). The Ministry of Economic Development proposed to limit the request to five top priority projects (Zvezda, the gas fields of Rospan, Russkoye and Yurubcheno-Tokhomskoye fields and the Achinsk refinery). The Ministry of Finance was, in principle, against the financing of oil projects from the National Wealth Fund and tried to bury Rosneft's application in endless delays (Papchenkova and Starinskaya 2015). Finally, in July 2015, Vladimir Putin decided not to allocate that money to Rosneft (Papchenkova and Fadeeva 2015).

The sanctions and low oil prices also forced Rosneft to revise its plans for offshore exploration. Rosneft requested Rosnedra to freeze the licences of certain projects in the Barents, Okhotsk, East Siberian and Pechora Seas in 2015 and the Black Sea in 2017 mainly because of the adverse effects of the Western sanctions, including the loss of foreign partners; these requests were partially granted (Kommersant 2017; Starinskaya 2015).

In short, Rosneft's main response to low prices, crises and sanctions has involved attempts (successful and unsuccessful) to halt certain projects and the use of its political connections to obtain financial benefits and financial support from the state. However, this point should not be overstated. Novatek, which is a fully privately owned company, received the funds it requested from the National Wealth Fund. Rosneft ultimately ended up relying more on Chinese capital.

\section{Climate Change}

As the world's largest publicly traded oil company by production, Rosneft's activities inevitably have a significant impact on the climate. However, Rosneft's stance on climate change is profoundly ambivalent.

According to its 2017 Sustainability Report, Rosneft sets GHG emissions reduction targets. The sustainability report also details the company's emissions for that year and its ongoing efforts to reduce them, including its Gas Investment Programme and Energy Efficiency Programme with a strong focus on the utilization of APG. In 2017, Rosneft's GHG emissions amounted to 76 million tonnes of $\mathrm{CO}_{2}$ equivalent, including direct emissions of 54 million tonnes and indirect emissions of 22 million tonnes related to heat and power consumption (Rosneft 2017, p. 82). This represented a 2\% decrease from the previous year despite the acquisition of Bashneft. The 2018 Sustainability Report states that the GHG emissions amounted to 76.4 million tonnes of $\mathrm{CO}^{2}$ equivalent, including 54.2 million tonnes of direct emissions and 22.2 million tonnes of indirect emissions. This means that they rose slightly from the preceding year (Rosneft 2018b, p. 73).

According to the Carbon Disclosure Project's 2017 Carbon Majors Report, the majority of the world's carbon emissions are the responsibility of 100 com- 
panies, many of which (unsurprisingly) are oil and gas companies (CDP 2017). Rosneft came 27th in this list, with lower cumulative emissions than Gazprom, ExxonMobil, Shell, BP, Total, ConocoPhillips and LUKOIL. According to their methodology, Rosneft's cumulative emissions between 1988 and 2015 represented $0.7 \%$ of global emissions. Gazprom came third with $3.9 \%$ of global emissions.

In its 2016 Sustainability Report, Rosneft claims that it is one of the pioneering oil companies in the world in terms of GHG emissions control. It says that it was the second-lowest among its competitors in terms of the ratio of the total volume of GHG emissions per thousand barrels of oil equivalent of production in 2015, according to Bloomberg's methodology. Rosneft also states that it had the lowest ratio of energy consumption per thousand barrels of oil equivalent of production in 2015 among peer companies (Rosneft 2016f, p. 29). According to the 2017 Sustainability Report, Rosneft has also been active in helping the government to develop effective climate legislation 'to enhance government regulation mechanisms for GHG emissions and drive the ratification procedure for the Paris Agreement', including efforts to reduce emissions in the public sector (Rosneft 2017a, p. 75).

In its 2018 Sustainability Report, Rosneft noted several measures to reduce GHG emissions such as reduced business trips, and increased emphasis on video conferencing. Moreover, the company launched several environmentally friendly gas filling stations and low emission products (new Pulsar 100 gasoline, Euro 6 and BP Active Fuel) (Rosneft 2018b, p. 76).

In the past, Rosneft was one of the worst offenders in Russia in terms of flaring APG; however, it is now making efforts to improve its performance in this area. For instance, in 2010, it commissioned a gas-processing facility and a $180 \mathrm{MW}$ gas turbine power station fuelled with APG in the Priobskoye field (Rosneft 2011). In 2011, Rosneft increased the level of APG utilization at Sevmorneftegeofizika to $95 \%$ within the framework of its Target Gas Programme. Rosneft reports that due to the implementation of its Gas Investment Programme and Energy Efficiency Programme, APG flaring from 2013 to 2016 decreased from 29\% to 9\% (Rosneft 2016f, p. 161). In 2018, Rosneft's level of APG utilization was 84\%, that is, lower than in 2017 (89\%) (Rosneft 2019b).

Rosneft has been involved in several joint implementation projects under the Kyoto Protocol. For instance, in March 2012, the Ministry of Economic Development approved Rosneft's APG utilization investment projects as a joint implementation project (Rosneft 2012d). The decision of the Ministry permitted Rosneft to sell units of GHG emission reductions to the investment company Carbon Trade \& Finance SICAR.

Although it may appear that Rosneft has been proactive about climate change and reported on its progress in its 2017 and 2018 Sustainability 
Reports, this has not always been the case, and improvements in reporting are the result of pressure from investors. It seems that Rosneft tends not to perceive all these issues as low-carbon alternatives aimed at climate change mitigation but rather as a chance to earn more money. Igor Sechin's ambivalent attitude can probably explain this indifference to climate change since Rosneft is very much a one-man show. According to Armitage (2015), Sechin once joked about how he had responded to a question from the audience about renewable energy at a public event:

I can tell you I am not a big expert in that area, but I know a few things. First of all, we are the subject of global climate change cycles. I actually comforted the guy. I said, 'those cycles repeat every 30 million years, so everything is normal. The human effect on the environment is less than any volcano. A volcanic eruption produces more $\mathrm{CO}_{2}$ than any human activity. The rotting of algae in the ocean significantly exceeds any human-made effect, so one should be calm about it'. (Igor Sechin, cited in Armitage 2015)

At the 2017 Saint Petersburg Forum, Igor Sechin discussed the prospects of electric cars, believing that they would occupy a market niche but not at the level anticipated by some actors. In general, he concluded that 'hydrocarbons were and would be in demand' (Igor Sechin, cited in Yeremenko 2017).

\section{Internationalization}

Rosneft's long-term objective is to become a global energy company. The company is internationalizing in two main directions: entering the upstream operations of other oil-producing countries around the world and building niches in the European and Asian downstream markets (Tables 2.5 and 2.6). Through its international partners in the Russian petroleum sector, Rosneft can have access to projects in third countries where the partners are well respected. It also interacts with other national oil companies overseas, both upstream and downstream.

Rosneft's international expansion has multiple drivers. First, like other major oil companies, Rosneft aims to diffuse risks and grasp different markets. Second, it hopes it can acquire technological know-how from foreign partners. Third, the company acts as a petroleum ambassador for Russia, helping to establish relations or strengthen ties with strategic allies, such as China, Cuba and Venezuela. Despite this, Rosneft's close links to the Russian state are sometimes a disadvantage since it is regarded in many countries as a tool of the Kremlin. Finally, like other major Russian companies, Rosneft's international forays reflect a unique post-Soviet yearning to be seen as an equal on the international scene with its unique agency and not as an entity that is mistrusted. 










Despite its ambitious globalization plans and large number of international projects, almost all of Rosneft's actual output is still concentrated in Russia, and the share of overseas projects in its oil production portfolio is only about 1\% (Interfax 2017). According to Chris Inchcombe, the Director of the International Projects Department, 'a company such as Rosneft should not strive to get access to all the regions of the world. We'll focus on where we already work and where we see real opportunities' (Interfax 2017).

Historically, Russia has always focused on energy exports to Europe. However, during the 2000s, Russia's attention started shifting from Europe, where demand was stagnating, to the Asia-Pacific market, especially China, while strengthening political and economic ties with both China and India. Another driver was the national interest in revitalizing Eastern Siberia and the Far East regions, which constitute $60 \%$ of Russia's territory but account for only $10 \%$ of its population. It was also necessary to establish a new petroleum province to supplement the ageing Western Siberian fields that currently account for $60 \%$ of Russia's crude production; Eastern Siberia and the Far East were next in line.

Thus, during the 2000s, Rosneft gradually displaced YUKOS and TNK-BP in the strategic Eastern region and began to implement the Asian vector of state energy policy. In addition to the national interests noted above, Rosneft also had its own long-term strategic considerations for going east: it wanted to carve out a solid chunk of the rapidly growing Chinese market and diversify its export routes. Meanwhile, close cooperation with Chinese NOCs also facilitated Rosneft's handling of the massive debts it had incurred through its policy of aggressive acquisition.

There was a breakthrough in Russian-Chinese oil relations when Rosneft acquired Yuganskneftegaz in 2004 and the Chinese banks lent Rosneft USD 6 billion to repay its debts (see above). Later, Rosneft actively lobbied for the construction of the ESPO pipeline and the spur to China. Rosneft is the main (and actively growing) supplier of Russian oil to the Asia-Pacific region (Overland and Kubayeva 2018) (Figure 2.1, see p. 50).

The share of Russian oil in the Chinese market is steadily growing. In 2014, Russia became the third supplier to China after Saudi Arabia and Angola. In 2016, the largest portion of China's 7.6 million barrels per day of crude imports was supplied by Russia (14\% of total imports), followed by Saudi Arabia (13\%), Angola (11\%) and Iraq (10\%) (Barron 2017). Sanctions became an additional driver of Rosneft's expansion to the Asia-Pacific, and in 2017, Russia delivered 1.2 million barrels per day to China, 14\% higher than in 2016 and ensuring that it remained the number one external supplier of oil to China (Vestifinance 2018). In 2018, Russia remained the number one external supplier of oil to China, with 1.43 million barrels per day (Oilcapital.ru 2019). 


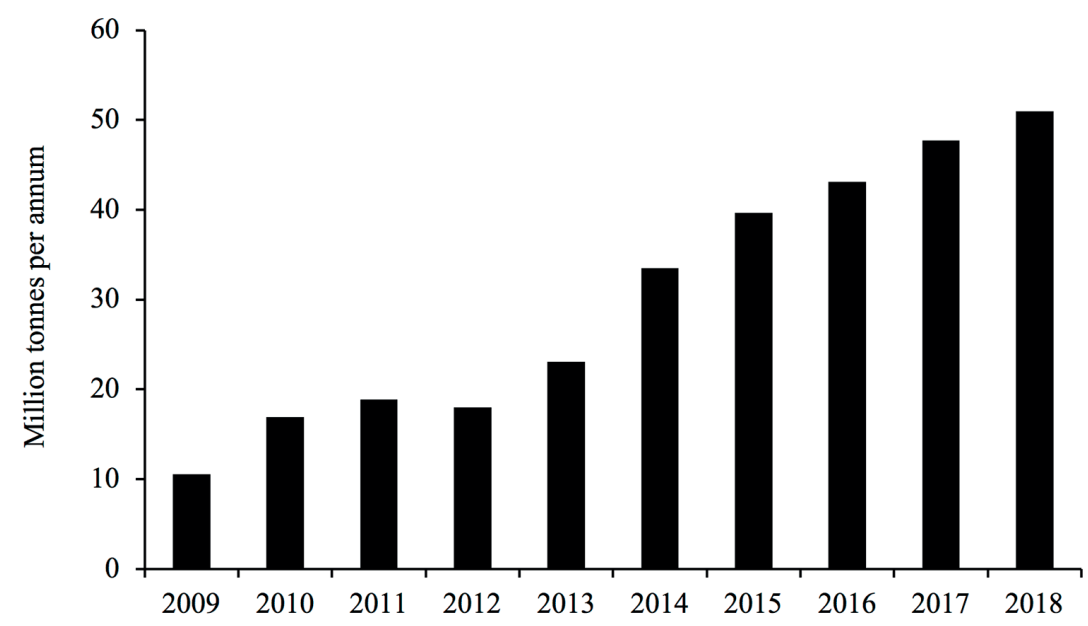

Figure 2.1 Rosneft's oil exports to the Asia-Pacific region (2009-18), million tonnes per year

Source: Rosneft's annual reports.

At the same time, since the mid-2000s, thanks to Rosneft, Chinese companies have also had access to the Russian upstream sector. In 2005, Rosneft invited Sinopec to buy $25 \%$ of the Veninsk block of Sakhalin-3. Sinopec committed itself to cover a proportion of Rosneft's exploration expenses and provide a certain amount of financing at the development phase (Rosneft 2012c). In August 2006, Sinopec purchased from TNK-BP 96.96\% of its subsidiary Udmurtneft for USD 3.5 billion through the company Promleasing. In December 2006, Rosneft exercised an option to buy $51 \%$ of Promleasing from Sinopec (AK\&M 2006).

Although the Chinese are highly interested in equity oil, they do not want to overpay for assets. As a result, certain Rosneft plans to establish E\&P partnerships with Chinese NOCs have failed. For instance, in 2013, Rosneft (51\%) and CNPC (49\%) agreed to form a joint venture based on Taas-Yuryakh Neftegazodobycha; however, the deal fell apart because the partners could not agree on the terms. In the same year, Rosneft signed several agreements with CNPC on joint activities in the Barents and Pechora Seas; however, disagreements over the prices, high costs and unclear economics of Arctic exploration hampered progress.

Also, on 9 November 2014, Rosneft and CNPC signed a framework agreement on the purchase of $10 \%$ of Vankorneft. The Chinese were apparently 
ready to buy a larger stake of Vankorneft; however, the deal fell through because the partners could not agree on the price. Later, on 7 November 2016, Rosneft and Beijing Gas Group signed an agreement to sell 20\% of the shares of Verkhnechonskneftegaz for some USD 1.1 billion; they also reached an agreement on cooperation in the gas sector.

Since relations with China were progressing mainly in oil-for-loans deals and failing in the joint development of Russian resources, Rosneft decided to renew its cooperation with India, which had initially been launched in 2001, by selling half of its share in Sakhalin-1 to the Indian Oil and Natural Gas Corporation (ONGC). In May 2016, Rosneft and ONGC closed the deal on the sale of a 15\% stake in Vankorneft for USD 1.27 billion. In October 2016, Rosneft sold another $11 \%$ of Vankorneft for USD 930 million to ONGC, making it the owner of $26 \%$ of Rosneft's subsidiary (Rosneft 2016c). Another deal was closed on 5 October 2016 for the purchase of $24 \%$ of Vankorneft by a consortium of Indian investors (Oil India, Indian Oil and Bharat PetroResources) for USD 2 billion (Rosneft 2016d). Thus, the stake of Indian companies in Vankorneft grew to $49.9 \%$. Rosneft retained a $51.1 \%$ majority in the board of directors; it also maintained its control over Vankorneft's operations and the production infrastructure of the Vankor cluster.

Vankor became the most significant, albeit not the only, breakthrough of India in the Russian upstream petroleum sector. In October 2016, Rosneft, Oil India, Indian Oil and Bharat PetroResources also agreed to trade 30\% of Taas-Yuryakh for USD 1.2 billion (Rosneft 2016e).

Rosneft also secured a niche in the downstream sector in India, the success of which should particularly be attributed to its ties with the Indian company Essar (Rosneft 2016a, p. 105). In August 2017, Rosneft and a consortium of investors closed a deal on buying 49\% of Essar Oil Limited (EOL) for USD 13 billion. Vadinar refinery, with a throughput capacity of 20 million tonnes per annum and a conversion ratio of $95.5 \%$, forms part of EOL. EOL also owns a network of 2.7 thousand fuel stations in India (Rosneft 2017e).

Under the pressure of sanctions, Rosneft managed to find another Asian partner. In October 2016, Rosneft and the Indonesian company Pertamina signed preliminary agreements envisaging the sale of stakes in the Russkoye field (up to $37.5 \%$ ) and in the northern part of Chaivo (up to 20\%). The partners also established a joint venture - Rosneft (45\%) and Pertamina (55\%) - to build the 15-million-tonne-per-annum Tuban refining and petrochemical complex on the island of Java (Fadeeva 2016c).

\section{CONCLUSION}

Rosneft mirrors the changes that took place in Russia between 1991 and 2020 as well as those that it sometimes initiated itself. As a response mechanism to 
external changes, Rosneft has often drawn on its formidable lobbying potential to protect itself or benefit from such changes, albeit with varying degrees of success. At critical times, Rosneft has been able to make use of state funds and state-sanctioned international relations to secure deals and develop its business. In return, it has provided support to the state in critical areas, such as development in post-war Chechnya or the less developed eastern regions of Russia; it has also played a crucial role in international energy diplomacy, notably with China. With Igor Sechin as CEO, Rosneft has launched many upstream and downstream international projects, driven by political and/or commercial reasons.

The company has managed to handle the challenges of fluctuating oil prices and the Western sanctions, partly because of its consistent monitoring of the oil prices and partly because of its close ties with the Kremlin; its success can also be ascribed to various strategic partnerships with foreign oil companies. Rosneft has also benefited from its diverse portfolio of projects within Russia thanks to numerous strategic acquisitions, state influence and access to financing. The company owns many downstream assets in both Russia and Europe, ranging from refineries to petrochemical businesses, gas-processing plants and gas stations.

Among its peers, Rosneft can hardly be distinguished for its environmental performance and standard social projects. However, the company appears to have modified its policy on transparency and reporting, notably concerning reporting on its GHG emissions and efforts to reduce its climate change impact. Having been one of the worst offenders among its peers in the past, Rosneft has been making concerted efforts to reduce its APG flaring. The company came out relatively favourably in a major report on the climate responsibility of major companies, although it remains among the top 30 international companies responsible for the largest part of global climate change, according to the Carbon Disclosure Project.

\section{NOTES}

1. This chapter title is partly inspired by Poussenkova (2007).

2. 'On Specifics of Privatization and Corporatization of the State Enterprises, Production and R\&D Associations of Oil Production, Refining and Marketing Segments'.

3. 'On Top Priority Measures to Improve Activities of the Oil Companies'.

4. The Samotlor field produced 150 million tonnes per annum at the peak in the 1980s. However, its production in 2019 was only some 20 million tonnes per annum. Due to excessive flooding during the communist era, the water-cut at Samotlor is $95.8 \%$. 


\section{REFERENCES}

AK\&M (2006), 'Rosneft planiruyet realizovat optsion na pokupku 51\% aktsiy Udmurtnefti', accessed 15 October 2018 at https://www.vedomosti.ru/library/news/ 2006/06/20/rosneft-planiruet-realizovat-opcion-na-pokupku-51-akcij-udmurtnefti.

Armitage, J. (2015), 'Igor Sechin: The oil man at the heart of Putin's Kremlin', Independent, accessed 12 October 2018 at http://www.independent.co.uk/news/ business/analysis-and-features/igor-sechin-the-oil-man-at-the-heart-of-putins -kremlin-10043230.html.

Barron, J. (2017), 'More Chinese crude oil imports coming from non-OPEC countries', accessed 12 October 2018 at https://www.eia.gov/todayinenergy/detail.php?id= 30792.

Barsukov, Y., D. Butrin and D. Kozlov (2016), 'Ne mytiem, tak Katarom', accessed 12 October 2018 at https://www.kommersant.ru/doc/3164301.

Bloomberg (2019), 'ROSN: LI', accessed 3 January 2019 at https://www.bloomberg .com/quote/ROSN:LI.

CDP (2017), The Carbon Majors Database, accessed 13 October 2019 at https:// 6fefcbb86e61af1b2fc4-c70d8ead6ced550b4d987d7c03fcdd1d.ssl.cf3.rackcdn.com/ cms/reports/documents/000/002/327/original/Carbon-Majors-Report-2017.pdf ?1501833772.

Derbilova, Y. (2006), 'Vsya pravda Rosnefti', accessed 11 October 2018 at https:// www.vedomosti.ru/newspaper/articles/2006/05/17/vsya-pravda-rosnefti.

Derbilova, Y. and V. Kudinov (2005), 'Bez Sberbanka ne oboshlis', accessed 11 October 2018 at https://www.vedomosti.ru/newspaper/articles/2005/08/26/bez -sberbanka-ne-oboshlis.

Derbilova, Y. and I. Reznik. (2010), 'Sergey Bogdanchikov pokinet Rosneft', accessed 12 October 2018 at https://www.vedomosti.ru/newspaper/articles/2010/09/01/dolgie provody.

Derbilova, Y. and V. Surzhenko (2006), 'Rosneft zadachu vypolnila', accessed 12 October 2018 at https:/www.vedomosti.ru/newspaper/articles/2006/07/17/rosneft -zadachu-vypolnila.

Derbilova, Y. and A. Tutushkin (2004), 'Nakhodchivaya Rosneft', accessed 23 January 2019 at https://www.vedomosti.ru/newspaper/articles/2004/03/24/nahodchivaya -rosneft.

Fadeeva, A. (2016a), 'Igor Sechin: Rosneft nuzhno prodavat pri tsene nefti v \$100 za barrel', accessed 12 October 2018 at https://www.vedomosti.ru/business/articles/ 2016/02/11/628482-sechin-rosneft-nuzhno-prodavat-tsene-nefti-100-barrel.

Fadeeva, A. (2016b), 'Rosneft i Statoil nashli vodu v Okhotskom more', Vedomosti, accessed 12 October 2018 at https://www.vedomosti.ru/business/articles/2016/09/ 29/658943-rosneft-statoil.

Fadeeva, A. (2016c), 'Rosneft prodaet indonezioskoi Pertamina doli v dvuh mestorozhdeniyah', accessed 12 October 2018 at https://www.vedomosti.ru/business/articles/ 2016/10/06/659794-rosneft-pertamina-mestorozhdeniyah.

Fadeeva, A. (2016d), 'Na Vankore nachalos snizheniye dobychi', accessed 23 January 2019 at https://www.vedomosti.ru/business/articles/2016/06/09/644700-vankore -dobichi.

Fadeeva, A., M. Papchenkova and T. Voronova (2016a), 'Rosneft doplatit budzhetu za sobstvennye aktsii', accessed 12 October 2018 at https://www.vedomosti.ru/ business/articles/2016/12/12/669144-rosneft-doplatit. 
Fadeeva, A., Y. Derbilova, M. Papchenkova and A. Terentyeva (2016b), 'Bashneft privatizirovana', accessed 15 October 2018 at https://www.vedomosti.ru/business/ articles/2016/10/13/660741-bashneft-privatizirovana.

Fjaertoft, D. and U. Overland (2015), 'Financial sanctions impact Russian oil, equipment export ban's effects limited', Oil and Gas Journal, 8 (113), 66-72.

Gavshina, O. (2011), 'Rosneft opyat lishilas britanskogo partnera', Vedomosti, accessed 12 October 2018 at https://www.vedomosti.ru/business/articles/2011/12/27/vr_sdala sahalin.

Gazeta.ru (2017), 'Tseny na neft: Vperedi padeniye', accessed 12 October 2018 at https://www.gazeta.ru/business/2017/09/11/10882958.shtml.

Gordeyev, V. (2017), 'Sechin predskazal vozvrasheniye tsen na neft k urovnyu 2016 goda', $R B C$, accessed 12 October 2018 at https://www.rbc.ru/finances/11/09/2017/ 59b617009a794709393eb56e.

Hudson, J. and N. Poussenkova (1996), Russian Oil, Prospects for Progress: Industry Background and Status, Volume 4 of Report on Russian Oil, London: Salomon Brothers.

Interfax (2017), 'Kris Inchkomb: Rosneft ne stremitsya dobyvat vo vsekh regionakh mira', accessed 12 October 2018 at https://www.interfax.ru/interview/550161.

Kalyukov, Y. (2015), 'Sechin predskazal rost neftyanykh tsen do $\$ 170$ za barrel k 2035 godu', $R B C$, accessed 12 October 2018 at https://www.rbc.ru/economics/19/06/ 2015/55843a319a79477a7a20e21f.

Kezik, I. (2013), 'Rosneft pokupayet dolyu v italianskom NPZ', accessed 12 October 2018 at https://www.vedomosti.ru/business/articles/2013/04/16/rosneft_propisalas na_sardinii.

Kommersant (2017), 'Rosneft iz-za sanktsiy priostanovila dobychu nefti na uchastke v Chernom more', accessed 12 October 2018 at https://www.kommersant.ru/doc/ 3453648.

Kozlov, D. (2017), 'Rosneft ishet vyhod iz Alzhira', accessed 12 October 2018 at https://www.kommersant.ru/doc/3186781.

Kozlov, D. and Y. Barsukov (2017), 'Rosneft doburila do lgot', accessed 12 October 2018 at https://www.kommersant.ru/doc/3433278.

Kozlov, D., A. Zanina and Y. Khvostik (2017), 'Statoil probilas skvoz slantsy', accessed 12 October 2018 at https://www.kommersant.ru/doc/3206767.

Kurmangazy-Kazakhstan Rosneft (2018), 'Istoriya', accessed 12 October 2018 at https://kurmankazah.rosneft.ru/about/Glance/OperationalStructure/Razvedka/ kurmankazah/.

Latyshova, E. (1995), 'Purneftegas uverenno shagaet vzad-vpered', Neft i kapital, 3, 46-51.

Malkova, I. (2009), 'V Rosnefti i TNK-VP massovye uvolneniya', accessed 12 October 2018 at https://www.vedomosti.ru/business/articles/2009/10/02/v-rosnefti-i-tnk-bp -massovye-uvolneniya.

Malkova, I. (2010), 'Rosneft v krizisnyy god uluchshila rentabelnost po EBITDA', accessed 12 October 2018 at https://www.vedomosti.ru/business/articles/2010/02/ 02/rosneft-v-krizisnyj-god-uluchshila-rentabelnost-po-ebitda.

Malkova, I. and Y. Derbilova (2008), 'Naperekor krizisu', accessed 12 October 2018 at https://www.vedomosti.ru/newspaper/articles/2008/11/10/naperekor-krizisu.

Markova, N. (2017), 'Gosorgany podtverdili otkrytiye Rosneftyu Tsentralno-Olginskogo mestorozhdenya na Taymyrye', accessed 12 October 2018 at http://neftianka.ru/ gosorgany-podtverdili-otkrytie-rosneftyu-centralno-olginskogo-mestorozhdeniya -na-tajmyre/. 
Mazneva, Y. and Y. Derbilova (2007), 'Rosneft spryatalas', accessed 11 October 2018 at https://www.vedomosti.ru/newspaper/articles/2007/05/18/rosneft-spryatalas.

Mazneva, Y. and V. Novyy (2010), 'Rosneft i Chevron sobirayutsya potratit na Chernom more 1 trln rub', accessed 12 October 2018 at https://www.vedomosti.ru/ business/articles/2010/06/18/rosneft-i-chevron-sobirayutsya-potratit-na-chernom -more-1-trln-rub.

Mazneva, Y., P. Sterkin and A. Fialko (2010), 'Rosneft nashla soyuznika na 3 milliarda', accessed 12 October 2018 at https://www.vedomosti.ru/newspaper/articles/ 2010/09/30/rosneft_nashla_soyuznika_na_3_mlrd.

Melnikov, K. (2011āa), 'Rosneft zaderzhitsya na Chernom more', accessed 12 October 2018 at https://www.kommersant.ru/doc/1621563?query= роснефть $\% 20$ черное\% $\%$ море.

Melnikov, K. (2011b), 'Rosneft podderzhit Venezuelu', accessed 12 October 2018 at https://www.kommersant.ru/doc/1827175.

Mescherin, A. (2005), 'Riskovannaya klounada', Neftegazovaya vertikal, 1, 5.

Neft i kapital (2003), 'Prirazlomnoe mestorozhdeniye: Vse uchteno', accessed 12 October 2018 at https://neftegaz.ru/news/view/42801-Prirazlomnoe-mestorozhdenie -vsyo-uchteno.

Neft i kapital (2004a), 'Rosneft', Neft i kapital, 10, 14.

Neft i kapital (2004b), 'Purneftegaz', Neft i kapital, 10, 60.

Neft i kapital (2004c), 'Sergei Bogdanchikov', Neft i kapital, 10, 161.

Neft i kapital (2004d), 'Neftyaniki vosstanavlivayut dobychu chernogo zolota v Chechne', accessed 12 October 2018 at https://neftegaz.ru/news/view/44660 -Neftyaniki-vosstanavlivayut-dobychu-chernogo-zolota-v-Chechne.

Newsru.com (2014), 'Sechin: Sanktsii protiv Rosnefti neobosnovannye, subyektivnye i nezakonnye', accessed 12 October 2018 at https://www.newsru.com/finance/ 17 jul2014/setchinsanct.html.

Newsru.com (2017), 'Sechin: nizkiye tseny na neft - eto nadolgo', accessed 12 October 2018 at https://www.newsru.com/finance/02jun2017/sechinforum.html.

NGFR (2008), 'Rosneft', accessed 23 January 2018 at http://www.ngfr.ru/library.html ?rosneft.

Oilcapital.ru (2019), 'Eksport rosiyskoi nefti v KNR v dekabre dostig $7.04 \mathrm{mln}$ tonn', accessed 26 November 2019 at https:/oilcapital.ru/news/markets/25-01-2019/ rossiya-snova-na-pervom-meste-po-postavkam-v-kitay.

Overland, I. and G. Kubayeva (2018), 'Did China bankroll Russia's annexation of Crimea? The role of Sino-Russian energy relations', in Helg Blakkisrud and Elana Wilson Rowe (eds), Russia's Turn to the East: Domestic Policymaking and Regional Cooperation, Cham: Palgrave Macmillan, pp. 95-118.

Overland, I., J. Godzimirski, L.P. Lunden and D. Fjaertoft (2013), 'Rosneft's offshore partnerships: The re-opening of the Russian petroleum frontier?', Polar Record, 249 (49), 140-53.

Papchenkova, M. and A. Fadeeva (2015), 'Vladimir Putin ne dast deneg Rosnefti', accessed 12 October 2018 at https://www.vedomosti.ru/business/articles/2015/08/ 06/603694-rosnefti.

Papchenkova, M. and G. Starinskaya (2015), 'Minfin ne khochet finansirovat neftyanye proyekty', accessed 12 October 2018 at https://www.vedomosti.ru/business/articles/ 2015/06/03/594925-minfin-ne-hochet-finansirovat-neftyanie-proekti.

Papchenkova, M. and P. Tretyakov (2014), 'Rosneft mozhet ne dozhdatsya iskomykh 2.4 trln rubley', accessed 12 October 2018 at https://www.vedomosti.ru/business/ articles/2014/11/06/vtoroj-krug-rosnefti. 
Papchenkova, M., M. Lyutova and P. Tretyakov (2015), 'Rosneft uvelichila spisok proektov v zayavke na dengi iz FNB', accessed 12 October 2018 at https://www .vedomosti.ru/business/articles/2015/01/23/rosnefti-malo-ne-byvaet.

Petleva, V. (2018), 'Uiti po kitaiski', accessed 23 January 2019 at https://www .vedomosti.ru/opinion/articles/2018/05/08/768869-uiti-po-kitaiski.

Petrachkova, A. and E. Derbilova (2007), 'Ne podelili Tomskneft', accessed 15 October 2018 at https://www.vedomosti.ru/newspaper/articles/2007/07/13/ne -podelili-tomskneft.

Politinformatsia (2015), 'Polnye sanktsionnye spiski SSHA, ES i Kanady protiv rossiskikh grazhdan i kompaniy', accessed 12 October 2018 at http://politinform .su/pervaya-polosa/21275-polnye-sankcionnye-spiski-ssha-es-i-kanady-protiv -rossiyskih-grazhdan-i-kompaniy.html.

Poluektov, N. (1998), 'Bazhaev vozvraschaetsya v Rosneft', accessed 23 January 2019 at https://www.kommersant.ru/doc/209543.

Poussenkova, N. (2007), Lord of the Rigs: Rosneft as a Mirror of Russia's Evolution, Houston, TX: James Baker Institute Publications.

Poussenkova, N. (2012), Novye Zvezdy Mirovoi Neftyanki: Istoriya Uspekhov $i$ Provalov Natsionalnykh Neftyanykh Kompaniy, Moscow: Ideya Press.

Poussenkova, N. and I. Overland (2018), 'Russia: Public debate and the petroleum sector', in Indra Overland (ed.), Public Brainpower: Civil Society and Natural Resource Management, Cham: Palgrave, pp. 261-89, accessed 3 January 2019 at https://www.researchgate.net/publication/320657842.

Razumovskiy, P. (2016), 'Rossiyskiy otvet na neftyanye potreseniya', accessed 12 October 2018 at https://www.gazeta.ru/business/2016/06/16/8312309.shtml.

RBC.RU (2018), 'Sechin i Alekperov dali prognozi po tsenam na neft na 2019 god', accessed 25 November 2019 at https://www.rbc.ru/rbcfreenews/ $5 \mathrm{c} 2385139 \mathrm{a} 794712 \mathrm{~d} 76 \mathrm{abc} 07$.

Rosneft (2011), 'Rosneft dovela uroven utilizatsii poputnogo gaza v OOO RN Sakhalinmorneftegaz do 95\%', accessed 12 October 2018 at https://www.rosneft.ru/ press/releases/item/114239/.

Rosneft (2012a), 'Rosneft i Statoil podpisali soglasheniya po sozdaniyu sovmestnykh predpriyatiy dlya provedeniya geologorazvedochnykh rabot na shelfe', accessed 12 October 2018 at https://www.rosneft.ru/press/releases/item/176919/.

Rosneft (2012b), 'Rosneft i Statoil podpisali Deklaratsiyu o berezhnom osvoyenii rossiyskogo Arkticheskogo shelfa', accessed 12 October 2018 at https://www .rosneft.ru/press/releases/item/18661/.

Rosneft (2012c), 'Na Veninskom uchastke proyekta Sakhalin-3 nachato burenie poiskovo-otsenochnoi skvazhiny', accessed 12 October 2018 at http://www.rosneft .ru/Upstream/Exploration/russia_far_east/sakhalin-3/.

Rosneft (2012d), 'Investitsionnye proyekty Rosnefti po utilizatsii poputnogo neftyanogo gaza utverzhdeny Ministerstvom economicheskogo razvitia Rossiyskoy Federatsii', accessed 12 October 2018 at https://www.rosneft.ru/press/releases/item/ $177633 /$.

Rosneft (2013a), 'Rosneft konsolidirovala 100\% TNK-BP', accessed 12 October 2018 at https://www.rosneft.ru/press/releases/item/177799/.

Rosneft (2013b), 'Rosneft priobretaet neftegazovye aktivy AK ALROSA', accessed 12 October 2018 at https://www.rosneft.ru/press/releases/item/22666/.

Rosneft (2013c), 'Rosneft i Novatek dogovorilis ob obmene aktivami', accessed 12 October 2018 at https://www.rosneft.ru/press/releases/item/48218/. 
Rosneft (2013d), 'Rosneft i Statoil prodvinulis v realizatsii proekta razrabotki trudnoizvlekaemykh zapasov nefti v Samarskoi oblasti', accessed 12 October 2018 at https:// www.rosneft.ru/press/releases/item/48196/.

Rosneft (2013e), 'Rosneft i ExxonMobil zavershili formirovaniye SP dlya razrabotki trudnoizvlekayemykh zapasov nefti Zapadnoi Sibiri’, accessed 12 October 2018 at https:/www.rosneft.ru/press/releases/item/48200/.

Rosneft (2014), 'Rosneft i BP podpisali soglasheniye po razrabotke domanikovykh otlozheniy', accessed 12 October 2018 at https://www.rosneft.ru/press/releases/ item $/ 153084 /$.

Rosneft (2015), 'Rosneft i PDVSA podpisali Memorandum v otnoshenii razvitiya prioritetnykh proyektov', accessed 12 October 2018 at https://www.rosneft.ru/press/ releases/item/174167/.

Rosneft (2016a), Annual Report 2016, accessed 11 October 2018 at https://www .rosneft.com/upload/site2/document_file/a_report_2016_eng.pdf.

Rosneft (2016b), 'Rosneft priobretayet dolyu v krupneishem gazovom mestorozhdenii Sredizemnogo morya', accessed 12 October 2018 at https://www.rosneft.ru/press/ releases/item/185061/.

Rosneft (2016c), 'Rosneft uspeshno zakryla sdelku po prodazhe 11\% AO Vankorneft ONGC Videsh Limited', accessed 12 October 2018 at https://www.rosneft.ru/press/ releases/item/184363/.

Rosneft (2016d), 'Rosneft uspeshno zakryla sdelku po prodazhe $23.9 \%$ AO Vankorneft konsortsiumu indiiskikh kompaniy', accessed 12 October 2018 at https://www .rosneft.ru/press/releases/item/183891/.

Rosneft (2016e), 'Rosneft zavershayet formirovaniye mezhdunarodnogo konsortsiuma na baze OOO Taas-Yuryakh Neftegazodobycha', accessed 12 October 2018 at https://www.rosneft.ru/press/releases/item/183889/.

Rosneft (2016f), Sustainability Report 2016, accessed 12 October 2018 at https://www .rosneft.com/upload/site2/document_file/RN_SR_2016_EN(2).pdf.

Rosneft (2017a), Sustainability Report 2017, accessed 20 January 2019 at https://www .rosneft.com/upload/site2/document_file/RN_SR2018_eng_web_1.pdf.

Rosneft (2017b), 'Rosneft nachala bureniye samoy severnoy skvazhiny na rossiyskom shelfe', accessed 12 October 2018 at https://www.rosneft.ru/press/releases/item/ $186075 \%$.

Rosneft (2017c), 'Company policy on sustainable development', accessed 20 January 2019 at https://www.rosneft.com/upload/site2/document_file/development_policy eng.pdf.

Rosneft (2017d), 'Rosneft i Respublica Sakha (Yakutiya) rasshiryayut sotrudnichestvo v sotsialnoy sfere', accessed 12 October 2018 at https://www.rosneft.ru/press/ releases/item/187609/.

Rosneft (2017e), 'Rosneft uspeshno zakryla strategicheskuyu sdelku po priobreteniyu 49\% Essar Oil Limited', accessed 23 January at https://www.rosneft.ru/press/ releases/item $/ 187525 /$.

Rosneft (2018a), 'Shelfovye proyekty', accessed 12 October 2018 at https://www .rosneft.ru/business/Upstream/offshore/.

Rosneft (2018b), Sustainability Report 2018, accessed 25 November 2019 at https:// www.rosneft.com/upload/site2/document_file/Rosneft_CSR18_EN_Book.pdf.

Rosneft (2019a), 'Mezhdunarodnoe sotrudnichestvo na shelfe RF', accessed 3 January 2019 at https://www.rosneft.ru/business/Upstream/icoorp/.

Rosneft (2019b), 'Proizvodstvenniye rezultaty za 12 mesyatsev i 4 kvartal 2018 goda', accessed 8 February 2019 at https://www.rosneft.ru/press/releases/item/193733/. 
Samoilova, N. (1998), 'Privatizatsiya Rosnefti', Kommersant, accessed 23 January 2019 at https://www.kommersant.ru/doc/194943.

Shvarts, E., A. Pakhalov, A. Knizhnikov and L. Ametistova (2018), 'Environmental rating of oil and gas companies in Russia: How assessment affects environmental transparency and performance', Business Strategy and the Environment, 27 (7), 1023-38.

Solodovnikova, A. (2013), 'Rosneft obnalichila TNK-BP', accessed 12 October 2018 at https://www.kommersant.ru/doc/2155473.

Starinskaya, G. (2015), 'Ne vremya dlya shelfa', accessed 12 October 2018 at https://www.vedomosti.ru/business/articles/2015/06/15/596298-rosneft-otkladivaet -burenie-na-semi-uchastkah-arkticheskogo-shelfa.

Stulov, M. (2016a), 'Bashneft "do pokupki” Rosneftiyu', accessed 12 October 2018 at https://www.vedomosti.ru/business/galleries/2016/10/12/660481-bashneft-do -pokupki-rosneftyu.

Stulov, M. (2016b), 'Igor Sechin poobeshchal za Bashneft bolshe vsekh', accessed 12 October 2018 at https://www.vedomosti.ru/business/articles/2016/10/03/659350 -sechin-poobeschal.

Stulov, M. (2016c), 'Pokupatelyam Rosnefti mogli pomoch Gasprombank i VBPP', accessed 12 October 2018 at https://www.vedomosti.ru/business/articles/2016/12/ 15/669856-pokupatelyam-rosnefti.

Surzhenko, V. and E. Mazneva (2007), 'Chto vyroslo, to vyroslo', accessed 11 October 2018 at https://www.vedomosti.ru/newspaper/articles/2007/05/04/chto-vyroslo-to -vyroslo.

Usov, I., A. Terentyeva, A. Fadeeva and V. Petleva (2015), 'Soyedinennye Shtaty rasshirili sanktsionnye spiski protiv Rossii', accessed 12 October 2018 at https:// www.vedomosti.ru/business/articles/2015/07/30/602923-soedinennie-shtati -rasshirili-sanktsionnie-spiski-protiv-rossii.

Vestifinance (2018), 'Rossiya ostalas krupneishim postavschikom nefti v Kitai v 2017 godu', accessed 23 January 2019 at https://www.vestifinance.ru/articles/96804.

Vinogradova, O. (2005) 'Echo YUKOSa', Neftegazovaya vertikal, 6, 29.

Yeremenko, Y. (2017), 'Sechin protiv Tesla: O pobede uglevodorodov nad electromobilyami i tsenakh na neft', accessed 12 October 2018 at http://www.forbes.ru/ biznes/345515-sechin-protiv-tesla-o-pobede-uglevodorodov-nad-elektromobilyami -i-cenah-na-neft. 